\title{
US bioethics panel poised to judge local review boards
}

Washington. Tighter supervision of the local ethics boards that themselves supervise research protocols is likely to be among the first topics considered by the new National Bioethics Advisory Commission, which is to report within a year on steps needed to protect human research subjects in the United States.

The first task of the 17-member commission, which was appointed in the summer by President Bill Clinton and is chaired by Harold Shapiro, the president of Princeton University, New Jersey, will be to assess the protection of research subjects.

But the commission will also advise both the administration and Congress on other bioethics issues, including the privacy of genetic information, protection of individuals from discrimination based on such data, and the patenting of human genes.

The National Institutes of Health (NIH) and the Department of Energy first asked for the commission to be set up in 1993, to deal with issues raised by genetics research.

Subsequently, however, a separate commission of inquiry into past abuses of the use of human subjects in radiation research found that existing procedures for providing protection were deeply flawed (see Nature 377, 374; 1995), and the Clinton administration asked the new commission to focus on this issue first. Its initial two-year mandate expires next October, but is certain to be renewed if Clinton is still in office.

At last week's meeting, several commission members queried the effectiveness of the Institutional Review Boards (IRBs) that approve research protocols at 450 institutions across the United States. Under the rules covering the use of human subjects in publicly funded research, which are voluntarily extended to privately funded research at most institutions receiving public funds, IRBs play a central role in ensuring that subjects are kept safe and properly informed.

Bernard Lo, director of the medical ethics programme at the University of California at San Francisco, said the commission may want "to reconsider if the IRB model [is] really up to the task" of protecting research subjects. Ezekiel Emanuel, another commission member and professor of medicine at the Dana-Farber Cancer Institute in Boston, Massachusetts, said that his experience with IRBs suggested that the system was "too haphazard". These criticisms were echoed by Shapiro, who told a press conference that "at least some of the IRBs do not understand the weight of responsibility that is on their shoulders".

But Gary Ellis, director of the Office of Protection from Research Risks (OPRR) at the NIH, who addressed the commission on protection of human subjects, defended the IRBs, arguing that they "bring good sense to the table and do the right thing". The main problem, Ellis said, was the lack of legal protection for those who took part in privately funded research not embraced by the current voluntary system. He urged the commission to "articulate a meaningful standard of protection for all human subjects".

Each government agency has submitted a report to the commission on its efforts to protect human subjects, and Shapiro has appointed Jim Childress of the religious studies department at the University of Virginia to head a subpanel to review these. Shapiro promised that the commission will make recommendations on the use of human subjects in research in its first annual report, which is due a year from now.

But the commission has yet to decide which genetics issues it can address. Francis Collins, head of the National Center for Human Genome Research at the NIH, said there was "a critical need to define and enforce conditions for access to and use of genetic information" and that the commission was well-placed to confront the issue.

Collins added that he considered the patenting of human genes a "less promising" area for it to pursue, as the positions of the US Patent and Trademark Office and of the Congress, and the propensity of either to listen to the commission, were unclear.

Indeed, one of the biggest challenges for the commission will be to get its voice heard in the public debate and in the Congress on the issues that it does raise. Administrative questions, such as a reform of IRBs, can be resolved through executive action alone, but larger themes tackled by the commission will require legislation. Whether Congress listens "will depend on the force of our arguments", says Shapiro, adding that Congress is "an important target" for the panel.

The commission will not consider issues that are largely internal to the research community - such as scientific misconduct or the politically explosive issue of embryo research. A previous National Bioethics Committee collapsed in 1989 after straying into that particular territory.

Jack Gibbons, the president's science adviser, said the commission will draw on work that has been done in other countries, including the United Kingdom. Shapiro said that the group will have an informal meeting with international experts at the forthcoming World Congress on Bioethics in San Francisco at the end of next month. The commission's initial funding level of $\$ 500,000$ a year is clearly inadequate, and will be raised to $\$ 1.5-\$ 2$ million, he said.

Colin Macilwain
France unveils plans for 'strategic' gene sequencing centre

Paris. The French government last week announced plans to start the construction of a FFr1-billion (US\$200-million) gene sequencing centre, with a capacity to sequence 20 to 30 megabases a year. The new centre will be built at Evry, on the outskirts of Paris, already home to the Généthon genome centre.

The centre will be headed by Jean Weissenbach, a researcher at the Centre National de la Recherche Scientifique (CNRS) who works at the Institut Pasteur in Paris. Weissenbach, along with Daniel Cohen, led the pioneering efforts of the Généthon centre to create maps of the entire human genome (see Nature 377 Suppl. , 367; 1995).

The costs of the centre, which will be set up as a subsidiary of CNRS, are estimated to be FFr60-FFr80 million next year, and between FFr80 and FFr100 million a year during its planned ten-year lifetime. It will employ 120-140 staff.

François d'Aubert, the secretary of state for research, points out that while France led early efforts to map the genome, it has until now lacked sequencing facilities on the scale of the Sanger Centre in Britain or several laboratories in the United States. The new centre will provide France with an entry into international efforts to sequence the genome, he says.

The announcement of the centre followed the meeting last week of the Interministerial Committee for Scientific and Technological Research (CIRST), a body set up in 1958 by General Charles de Gaulle, but which last met in 1982 . The meeting was chaired by Alain Juppé, the prime minister.

The genome centre is one of four 'strategic' programmes announced at the meeting, intended to orient French research more towards the creation of wealth. The others involve support for industrial chemistry, biotechnology and microbiology. The main trade union representing researchers - the SNCS has already criticized this shift of empasis as representing a threat to fundamental research, as the money for the new programmes will have to be found from within a shrinking research budget.

One major change that was announced at the meeting, and issued as a decree on the same day, is the abolition of the ceiling on the amount of income that publicly funded researchers may earn from royalties on their inventions. "Researchers can at last become rich from their efforts," said François Bayrou, the minister for education and research.

Declan Butler 